\title{
Russian Constructions with Syntactic Reduplication of Colour Terms: A Corpus Study
}

\author{
Valentina Apresjan \\ National Research University Higher School of Economics \\ 20 Myasnitskaya st., Moscow, 101000, Russia \\ Vinogradov Russian Language Institute of the Russian Academy of Sciences \\ 18/2 Volkhonka st., Moscow, 119019, Russia
}

\begin{abstract}
Russian reduplicated constructions with colour terms have never previously been an object of a comprehensive corpus study. Nevertheless, they present considerable interest for a researcher because comparative ability of colour terms to be reduplicated reflects their semantic and pragmatic differences, whereas semantics and pragmatics of reduplication construction are revealed in the properties of colour terms that can fill its slots. Thus, the goal of the paper is to study semantic and pragmatic properties of Russian colour terms and Russian syntactic reduplication construction by analyzing their co-occurrence. We apply corpus methods to the data from the Russian National Corpus, RuTenTen Corpus on Sketch Engine and RuSkell corpus. We analyze absolute corpus frequencies and collocation patterns of Russian non-reduplicated colour terms, as well as their relative frequencies and collocation patterns in the construction of syntactic reduplication with a hyphen (belyj-belyj 'white-white, very white, spotlessly white'). Drawing on this data, we establish that absolute frequencies of non-reduplicated colour terms in Russian reflect both Anna Wierzbicka's "universals of visual semantics", as well as certain language and culture-specific tendencies, as evidenced by the prominence of goluboj 'light blue' and ryzhij 'carroty-red' in Russian. We also argue that the Russian reduplication construction with a hyphen (belyj-belyj 'white-white) is semantically and prosodically different from the construction of repetition with a comma (belyj, belyj 'white, white'). The former has the meaning of high degree, and thus attracts only gradable colour terms, such as belyj 'white', chernyj 'black', sinij 'medium to dark blue', and other basic colour terms. There are additional factors that influence colour term reduplication. Collocation patterns suggest that colour terms that co-occur with the names of culturally and cognitively salient objects, such as denotations of human appearance (face, hands, skin, eyes, hair) or landscape features (sea, sky, fire, grass) are more likely to be reduplicated. Moreover, aesthetic or emotional evaluation of such objects ('blue-blue eyes', 'green-green grass') is also a factor that is conducive to their occurrence in the construction of reduplication. Our findings establish the importance of corpus methods in the study of colour terms and reduplication, demonstrate that the use and interpretation of lexical and syntactic items hinges both on semantic and pragmatic factors, and add to the understanding of semantics and pragmatics of Russian colour terms and reduplication construction.
\end{abstract}

Keywords: reduplication, construction, collocation, colour term, gradable 


\title{
Русские конструкции с синтаксической редупликацией цветообозначений: корпусное исследование
}

\author{
В.Ю. Апресян \\ Национальный исследовательский университет «Высшая школа экономики» \\ Мясницкая, 20, Москва, 101000, РФ \\ Институт русского языка им. В.В. Виноградова РАН \\ Волхонка, 18/2, Москва, 119019, РФ
}

\begin{abstract}
Аннотация
Русские конструкции с редупликацией цветообозначений никогда ранее не становились объектом отдельного корпусного исследования. При этом они представляют явный интерес для исследователя, поскольку данные об их взаимной встречаемости могут пролить свет на семантику и прагматику как самих цветообозначений, так и конструкции с редупликацией. Цель данной работы - описание семантических и прагматических свойств русских обозначений базовых цветов, а также русской конструкции с полной синтаксической редупликацией на основе корпусного анализа их взаимной встречаемости. В работе используются данные разных подкорпусов Национального корпуса русского языка, корпуса RuTenTen на pecypce Sketch Engine и корпуса RuSkell. На основе анализа абсолютных частотностей употребления нередуплицированных цветообозначений, а также их коллокацинных свойств устанавливается иерархия базовых для русского языка цветов, которая отражает как межъязыковые «универсалии визуальной семантики» Анны Вежбицкой, так и лингвоспецифичные тенденции (например, базовость голубого и рыжего). На основе анализа редуплицированных цветообозначений формулируется значение русской конструкции с редупликацией прилагательных. Ее основное значение - это значение высокой степени, поэтому она «привлекает» наиболее градуируемые из цветообозначений, а именно «базовые цвета» - белый, черный, синий и пр. Употребление цветообозначений в конструкции редупликации дополнительно регулируется прагматически: анализ сочетаемости показывает, что к редупликации тяготеют те цветообозначения, которые используются для характеристики внешности человека или воспринимаемых человеком природных объектов с эстетической точки зрения или точки зрения нормы. Исследование демонстрирует важность корпусных методов в исследовании редупликации цветообозначений, показывает, что узус и интерпретация лексических и грамматических языковых единиц зависят как от семантических, так и от прагматических факторов, расширяет представление о семантике и прагматике русских цветообозначений, а также русской конструкции с синтаксической редупликацией.
\end{abstract}

Ключевые слова: редупликация, конструкиия, коллокация, иветообозначение, градуируемый

\section{INTRODUCTION}

Both reduplication and colour terms separately have received a lot of attention in linguistics. Anna Wierzbicka authored a number of seminal papers on colour terms in different languages including Russian, as well as on reduplication (Wierzbicka 1990, 1991, 2003, 2005, 2008). Moreover, Russian constructions with reduplication have been receiving growing coverage in recent decades (Paillard, Plungian 1993, Bulygina, Shmelev 1997, Israeli 1997, Krjuchkova 2004, Iomdin 2003, 2010, 2013, Gilyarova 2010, Rakhilina, Plungian 2010, Vilinbakhova 2016, Feldstein 2016). Russian colour terms have also been thoroughly studied, from different perspectives: (Davies, Corbett 1994) from experimental and statistical perspectives, (Paramei 2005) from a cultural 
perspective, (Paramei 2007) from a language acquisition perspective, (Winawer, Witthoft, Frank, Wu, Wade, Boroditsky 2007) from a psycholinguistic perspective.

However, so far there has been, to our knowledge, no attempt to juxtapose these two topics. Yet the issue appears to be of paramount interest: the ability of colour terms to be reduplicated reflects their semantic and pragmatic differences, whereas the semantics and pragmatics of the syntactic reduplication construction are revealed in the properties of colour terms that can fill its slots. Thus, the main focus of the paper is syntactic reduplication of Russian colour terms. The paper aims, in particular, at the following:

1) to formulate the meaning of the Russian construction with syntactic reduplication;

2) to consider its semantic shifts in different instantiations;

3) to show how different colour terms interact with reduplication construction and why certain colour terms are "attracted" to it, while others are "repelled" (Stefanowitch, Gries 2003);

4) to analyze different possible interpretations of reduplication construction depending on the colour term that fills its slots.

As it turns out, the arguments derived from our study support the previous findings in the field. First of all, they support Anna Wierzbicka's idea that colour concepts are anchored in "universals of human experience", such as the sun, the sky, the ground, day and night, vegetation, and fire (Wierzbicka 1990). They also provide certain linguistic endorsement to the existence of a hierarchy of colours introduced in (Berlin, Kay 1969), although at the same time pose strong challenges for it, along the lines of Wierzbicka's criticism of Berlin and Kay's "Anglocentric" approach to colour lexicon. Finally, they concur with the results of the above-mentioned cultural and experimental studies, because they also substantiate the claim for the "basicness" of the Russian goluboj 'light-blue' colour term. In addition, our findings suggest that the Russian colour term ryzhij 'carroty-red' also has certain properties specific to basic colour terms.

Our understanding of "basicness" of a colour term is different from what is suggested in [Berlin and Kay 1969]. The "basicness" of any concept for a specific language, including colour terms, is evaluated based partly on its frequency (and hence salience) in a given language, and partly on the degree of its integration into the lexical and grammatical system of that language. The latter is measured by the ability of a word to function as a "system-forming meaning", or "a meaning which constitutes part of many linguistic items of different nature" (Apresjan 2006:52). In the language of NSM, the notion of system-forming meaning fairly closely corresponds to the notion of "semantic molecule" — a well-defined set of non-primitive lexical meanings in a given language that function as intermediate-level units in the structure of complex meanings in that language (Wierzbicka 2013). There are reasons to believe that basic colour terms belong to the set of system-forming meanings, as they are integrated into the meanings of many natural objects, such as animals, plants, minerals, etc. Apart from its entrenchment in the semantic domain, we assume that the degree of a word's integration into the system of a language is also reflected in its ability to occur in different lexical and grammatical contexts, including constructions. 
Syntactic reduplication here is understood as in A. Wierzbicka's 1991 work on Italian reduplication where it is considered as semantically and pragmatically distinct from repetition; cf. adagio adagio (syntactic reduplication) vs. adagio, adagio (repetition) (Wierzbicka 1991:256). A later work by A. Israeli, which contains an excellent overview of research on Russian reduplication and repetition, supports this distinction, yet on prosodic grounds: "Syntactic reduplication is defined here as a repetition of a word (or a modified word) within the same prosodic unit, regardless of whether the two words are separated in print by a space, a hyphen, or a comma" (Israeli 1997:588). However, there is a distinct difference in properties between the constructions marked by a hyphen and by a comma: the former displays characteristics typical of syntactic reduplication (including prosodic unity), and the latter behaves, prosodically and semantically, as repetition (see commentary below). Therefore, we consider construction with hyphen as syntactic reduplication, and construction with comma as repetition.

Reduplication of colour terms is considered against the larger background of other Russian constructions with reduplication. A brief examination of possible instantiations of syntactic reduplication construction reveals that its core meaning is 'high degree' and that in different contexts it may display different semantic effects. Interpretation depends on the speech part of the lexeme filling the construction slots, as well as on its semantics.

With nouns, full "hyphen" reduplication is (a) occasionally used to express the meaning of large quantity: Sornjaki-sornjaki povsjudu 'Weeds-weeds are everywhere'; (b) used as vocative aimed at soliciting particular attention: Devochka-devochka, kak tebja zovut 'Girl-girl, what is your name?'; (c) used to refer to the most prototypical members of a class: Ona takaja devochka-devochka 'She is such as girl-girl; She is such as typical girl'. The latter interpretation, as well as certain other semantic effects of syntactic repetition in Russian nouns have been thoroughly described in (Gilyarova 2010).

With verbs, it marks (a) long duration: Shel-shel i prishel 'Walked-walked and came', Dumal-dumal, no nichego ne pridumal 'Was thinking-was thinking but thought of nothing' (Plungian, Rakhilina 2010); (b) strong stimulation in imperative: Rabotajrabotaj 'Work-work'.

With particles, it (a) emphasizes the meaning of the particle: $D a$ - $d a$ 'yes-yes', net-net 'no-no', konechno-konechno 'certainly-certainly'; (b) in some cases, reduplicated particles are lexicalized as new meanings, consider the reduplication of tol' $k o$ 'only': My tol'ko-tol'ko uspeli na poezd 'We barely (lit. only-only) made it to the train'.

With adverbs, interpretation of reduplication depends on the semantic class of the adverb. Gradable adverbs behave as adjectives and produce a high degree interpretation (tixo-tixo 'quietly-quietly' = 'very quietly'). Certain other adverbs that allow reduplication display effects of lexicalization; e.g. ele 'barely' vs. ele-ele 'barelybarely'. Single ele has two well-represented meanings: 'with great difficulty' (On ele podnjal tjazhelyj rjukzak 'He barely lifted a heavy backpack') and 'almost not' (ele zametnyj 'barely visible'). Reduplicated ele-ele demonstrates overwhelming preference of the first meaning: based on the frequency data from the Russian National Corpus, collocation ele-ele zametnyj 'barely-barely visible' forms only 0.4 per cent of its total usages, whereas the relative frequency of the collocate ele zametnyj 'barely visible' to the total usages of ele is 7 per cent. 
However, the main instantiation of syntactic reduplication marked by a hyphen are gradable adjectives. The major semantic classes of gradable adjectives that favor reduplication are parameters (size, duration, etc.) and physical properties (temperature, texture, colour, etc.): bolshoj-bolshoj 'big-big', dolgij-dolgij 'long-long', xolodnyjxolodnyj 'cold-cold', mjagkij-mjagkij 'soft-soft', chernyj-chernyj 'black-black'.

The latter semantic class is the major focus of the paper. The paper is structured in the following way: a brief outline of the methodology and data; the main part with results and discussion, which covers the use of non-reduplicated and reduplicated colour terms in Russian, a brief comparison of the Russian data with English, and a quick case study of register limitations of colour reduplication construction in Russian. The last section offers conclusions.

\section{METHODOLOGY AND DATA}

The study is based on the data from different subcorpora of the Russian National Corpus, RuTenTen corpus on Sketch Engine (Kilgariff, et al. 2014), and RuSkell learner corpus (Apresjan, et al. 2016). The main corpus of the Russian National Corpus reflects the literary Russian language of the 19-21 centuries and comprises over 280 million tokens. The children's subcorpus is over 5.8 million tokens and comprises literature intended for children. Poetic corpus of the Russian National Corpus reflects the language of poetry in 19-21 centuries, and contains over 10 million tokens. Finally, the parallel English-Russian corpus of the Russian National Corpus contains original and translated English, American and Russian literature of the 19-21 centuries and contains over 76 million tokens. RuTenTen Corpus on Sketch Engine is made up of texts collected from the Internet and contains over 18 billion tokens. It provides detailed word sketches (collocation patterns) for verbs, nouns, adjectives, and adverbs. RuSkELL is its learner subcorpus which provides brief and simplified word sketches and contains 1 billion tokens.

The study is based on the following assumptions:

(1) frequency of a certain word in the corpus of a particular language is indicative of the semantic "basicness" of this word in the lexicon of that language, as well as of the salience of a concept denoted by this word in the corresponding culture;

(2) frequency of a certain word in a certain construction is indicative of the general frequency of this word and construction in the corpus, as well as of semantic compatibility between the meaning of the word and the meaning of the construction.

Therefore, the study comprised two experimental stages, the frequency analysis of unreduplicated colour terms and the frequency analysis of reduplicated colour terms. We also considered collocation patterns for both unreduplicated and reduplicated colour terms. We considered only those colour terms that allow reduplication. Therefore, we excluded from our consideration such terms as fioletovyj 'purple', oranzhevyj 'orange', rozovyj 'pink', serebrjanyj 'silvery' and many other non-basic, borrowed, or derivative colour terms that either do not allow reduplication at all or else present only occasional reduplicated usages. Below are the statistical data of both usage types, along with explanations and analysis. 


\section{RESULTS AND DISCUSSION}

\subsection{Non-reduplicated colour terms: statistics and analysis}

As of June 2, 2018, the absolute frequency of the colour terms in the Russian National Corpus was as follows:

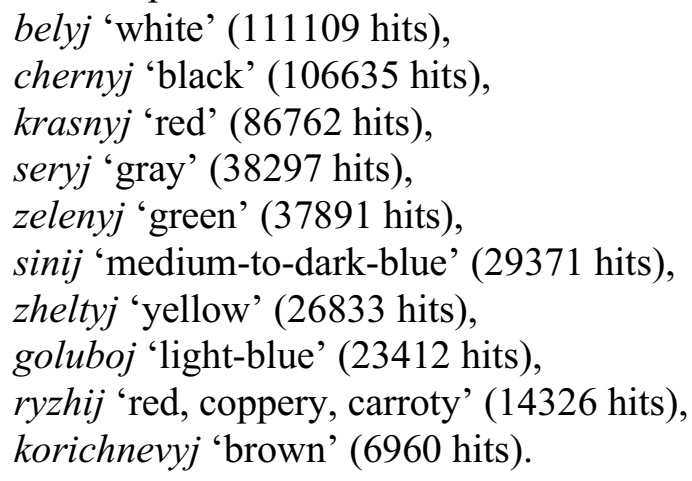

This data conforms with the earlier data from the New Frequency Dictionary of the Russian Lexicon by Olga Lyashevskaja and Sergey Sharov 2009 (online version on dict.ruslang.ru/freq.php); the first number shows the position of the word in the frequency hierarchy, and the second its relative frequency in items per million, or ipm. As one can easily observe, the "top" colour terms are also close to the top in the overall frequency of Russian adjectives:

21 'white' 339.6

23 'black' 337.5

39 'red' 240.5

121 'green' 124.4

170 'gray' 96.1

213 'medium-to-dark-blue' 82.8

219 'yellow' 78.1

233 'light-blue' 71.5

383 'carroty-red' 43.2

632 'brown' 25.5

Both sets of data reflect total usages of colour terms, in the entirety of their polysemies, i.e., such metaphorical usages as "black market", "white magic", "gray person" (untalented, uninteresting), etc., and not only their "colour" meanings, because developed polysemies are also indicative of the "basicness" of concepts.

As one can observe, absolute frequency of colour terms in RNC in some ways parallels the hierarchy suggested in Berlin and Kay "Basic Colour Terms: their Universality and Evolution" (1969): dark and light (Stage I), red (Stage II), green or yellow (III), green and yellow (IV), blue (V), brown (VI), purple, pink, orange, gray (VII). Russian 'white', 'black', 'red' and 'green' form the top in terms of frequency. However, there are also certain deviations from Berlin-Kay hierarchy. First of all, each of the terms for 'blue' is lower on the hierarchy of frequency than 'gray', and 'yellow' is lower that 'medium-to-dark-blue' (however, together 'medium-to-dark-blue' and 'light blue' rank 
over 'gray'). 'Carroty red' (a shade of orange) is higher than 'brown'. In other words, 'gray' and 'carroty red' are unexpectedly high, and 'yellow' is unexpectedly low. The discrepancy between Berlin-Kay hierarchy and the frequency data in Russian may point to the fact that relative importance of colour terms is language and culture-specific rather than universal.

Our assumption is that the hierarchy of absolute frequencies of colour terms reflects certain cultural and cognitive trends. To study these trends, we turn to the analysis of collocations with colour terms, based on the data from RNC, as well as on collocation sketches from the Sketch Engine and RuSkell (ruskell.sketchengine.co.uk).

Below is the list of frequent collocations with colour terms, which account for most of their occurrences in the corpus:

belyj 'white': 'dress', 'coat', 'house'; 'wine', 'sea', 'bear', 'sand' chernyj 'black': 'sea', 'bread', 'hair', 'eyes', 'dress', 'hair', 'tea', 'metal', 'pepper' krasnyj 'red': 'army', 'square', 'wine', 'banner', 'sea', 'pepper', 'brick', 'cross' zelenyj 'green': 'tea', 'onions', 'eyes', 'grass', 'leaves', 'peas', 'salad', 'pepper', 'leaf' sinij 'medium-to-dark-blue': 'sky', 'eyes', 'beard', 'bird', 'flame', 'sea', 'jeans' seryj 'gray': 'building', 'granite', 'eyes', 'mouse', 'wolf', 'goose', 'matter', 'sky' zheltyj 'yellow': 'press', 'card', 'fever', 'gold', 'flower', 'gold', 'sand' goluboj 'light-blue': 'sky', 'eyes', 'screen', 'blood', 'fire', 'clay', 'dream' ryzhij 'red, coppery, carroty': 'fox', 'hair', 'cat', 'cockroach', 'cow' korichnevyj 'brown': 'sugar', 'rice', 'crust', 'jacket', 'mascara'

The analysis of these sketches suggests that the factors influencing corpus frequencies of colour terms are as follows:

(1) ability of colour terms to characterize parts of human body and landscape: golubye glaza 'light-blue eyes', sinie glaza 'bright-blue eyes', serye glaza 'gray eyes', belye zuby 'white teeth'; ryzhyie volosy 'coppery-red hair', zelenaja trava 'green grass', goluboe nebo 'light-blue sky', etc.;

(2) cultural salience of objects of certain colours in a given language, such as the Russian belyj khalat 'white coat' (frequent expression used for metonymic reference to doctors, who typically wear white coats in Russia), seryj dom 'gray building' (a frequent artifact of Soviet architecture of the 60s-70s), ryzhaja lisa 'carroty-red fox' (a popular antihero in Russian animal folk tales), etc.;

(3) ability of colour terms to be used for classifying purposes, in idiomatic or terminological expressions: beloje vino 'white wine', belyj medved' 'white bear (Polar bear)', bereza belaja 'white birch', chernyj khleb 'rye bread, literally: black bread', Krasnaja armija 'the Red Army', krasnyj flag 'red flag', etc.

Thus, the objects that can be characterized by colour terms comprise, partly, certain "universals of human experience" in Anna Wierzbicka's terms, for example, the landscape surrounding human beings - the sky, the sun, the grass, the fire, etc. This explains the relative frequency of different hues of 'blue', of 'red', 'green', 'black', and 'white'.

Partly these objects are characteristics of human appearance. Our assumption is that colour terms that are used to characterize human appearance will gain cultural prominence in corresponding languages. That is the explanation of the frequency of the 
'blue' and 'gray' specter in Russian, which appears to contradict Berlin-Kay hierarchy; apart from being the primary colours that describe the sky, sinij 'medium-to-dark-blue', goluboj 'light-blue' and seryj 'gray' are also prominent eye colour characteristics. The same factor explains the relative prominence of ryzhij 'red, coppery, carroty' colour in Russian. Unlike the borrowed term oranzhevyj 'orange', ryzhij is fairy frequent in the corpus (14326 hits for ryzhij in RNC vs. 3944 hits for oranzhevyj). This is likely due to the fact that ryzhij 'red, coppery, carroty' is mostly used to describe hair colour in humans and animals, especially in foxes (important antiheroes of Russian folktales).

Interestingly, korichnevyj 'brown' that is also a widespread colour of eyes and hair, does not gain cultural prominence, which is probably due to the fact that it is not used in Russian in reference to eye or hair colour. There are special terms that denote 'brown' in these contexts: karij 'brown (in reference to eyes)', kashtanovyj 'chestnut; brown (in reference to hair)', gnedoj, kauryj 'chestnut (in reference to equine coat colour)'. Zheltyj 'yellow' is fairly infrequent, too, because it is not used in Russian in reference to blonde hair: zheltye volosy 'yellow hair' could only refer to artificially dyed hair, unlike the English yellow hair that can describe a naturally blonde shade.

Finally, these objects constitute different varieties of artifacts, animals, plants and all other kinds of objects, including historical and cultural objects, that form day-to-dayrealities, social environment and cultural background of language speakers: belaja bumaga 'white paper', belaja rubashka 'white shirt', krasnyj kirpich 'red brick', zheltyj pesok 'yellow sand', zheltaja pressa 'yellow press', Krasnyj krest 'Red cross'. Possibly due to the peculiarities of Soviet architecture, 'gray' has become a very prominent colour. It is also a standard metaphorical term for mediocrity. Very frequently the combinations of colour terms and nouns become idiomatic and turn into fixed expressions or terminology: Krasnaja armija 'Red army', krasnoje vino 'red wine', belyj flag 'white flag', and others.

Therefore, the most frequent colour terms are the ones that typically characterize landscape, human appearance, and culturally salient objects - and thus form the largest number of collocations and fixed expressions. For Russian, goluboj 'light blue' and ryzhij 'carroty red' at least partly answer these criteria, which explains their relatively high frequencies. This finding supports (Paramei 2005), where goluboj 'light blue' is interpreted as the twelfth basic colour, on the grounds of its symbolic and cultural value for Russian. In (Davies, Corbett 1994) goluboj 'light blue' is also established as the twelfth basic colour on experimental and statistical grounds.

Thus, corpus data suggest that linguistic hierarchies of colour basicness can vary across languages, as culturally salient objects do.

\subsection{Reduplicated colour terms: statistics and analysis}

To avoid bias, we measured not absolute, but relative frequencies of colour terms reduplication, namely, the ratio of reduplicated usages to non-reduplicated. Below are the percentages of reduplicated usages among the total usages for all basic colour terms:

$0.8 \%$ sinij-sinij 'medium-to dark-blue-medium-to-dark blue'

$0.34 \%$ of belyj-belyj 'white-white'

$0.24 \%$ of chernyj-chernyj 'black-black' 
$0.2 \%$ of ryzhij-ryzhij 'carroty-carroty'

$0.17 \%$ of goluboj-goluboj 'light blue-light blue'

$0.11 \%$ of seryj-seryj 'gray-gray'

$0.1 \%$ krasnyj-krasnyj 'red-red', zelenyj-zelenyj 'green-green', zheltyj-zheltyj 'yellow-yellow'

Korichnevyj-korichnevyj 'brown-brown' does not occur in the corpus. One can immediately observe that the hierarchy of reduplication is not the same as the hierarchy of "basicness" for Russian colour terms. Thus, sinij-sinij 'medium-to dark blue-mediumto-dark blue' occupies the top position, belyj-belyj 'white-white', chernyj-chernyj 'blackblack', ryzhij-ryzhij and goluboj-goluboj 'light blue-light blue' are in the middle, whereas seryj-seryj 'gray-gray', krasnyj-krasnyj 'red-red', zelenyj-zelenyj 'green-green' and zheltyj-zheltyj 'yellow-yellow' are in the bottom part. Therefore, the "basicness" of colour cannot be considered as the only factor affecting reduplication, and one must turn elsewhere to explain these data.

First of all, let us consider the semantics of Russian reduplication construction with a hyphen. Unlike Italian reduplication (Wierzbicka 1991), in Russian adjectives reduplication produces the interpretation of high degree. According to the bigrams in the Russian National Corpus, only qualitative adjectives are reduplicated (dlinnyjdlinnyj 'long-long', teplyj-teplyj 'warm-warm', etc.); relative adjectives are not; cf. the non-felicity of *derevjannyj-derevjannyj dom 'wooden-wooden house'). They cannot even be repeated because repetition contains an indication of high degree, too (*derevjannyj, derevjannyj dom 'wooden, wooden house'), unless repetition construction is used to express confirmation: - Dom derevjannyj? - Derevjannyj, derevjannyj ' - Is the house wooden? - Wooden, wooden'.

If a relative adjective is reduplicated or repeated, it can only be in a metaphorical, qualitative meaning. Consider the following examples with zolotoj 'golden' where the 'golden colour' interpretation is used with reduplication, and the 'good person' interpretation is used with repetition: Zolotye-zolotye, kak plamja svechi, mnogochislennye kupola 'Golden-golden, as candle flame, numerous domes' (S. M. Golicyn); My s nim teper' krepko sdruzhilis', potomu chto on byl zolotoj, zolotoj chelovek 'We now made very good friends with him because he was a golden, golden person' (V. Dragunskij).

Thus, in order to be able to appear in construction with reduplication, a colour term has to be gradable, because the meaning of the construction is high degree. Therefore, one factor that affects the ability of colour terms to be reduplicated is their gradability. Indeed, all colour terms that can occur with reduplication, can be defined by an intensifier ochen' 'very' and have comparative forms, which means they are gradable: ochen' chernyje brovi 'very black eyebrows', ochen' belye ruki 'very white hands', ochen' krasnye guby 'very red lips', ochen' golubye/sinie glaza 'very light blue/ medium to dark blue eyes', ochen' zelenaja trava 'very green eyes', ochen' zheltyj pesok 'very yellow sand', ochen' ryzhie volosy 'very carroty red hair', ochen' seryj den ' 'very gray day'. Colour terms that cannot occur with reduplication, cannot co-occur with 'very' and have no comparatives: *ochen' korichnevyj 'very brown', *korichnevee 'browner'. 
However, what is high degree with respect to colours? It seems that depending on the colour, it can mean different things. It some ways, high degree means closeness to the prototype, but for chromatic and achromatic colours prototypes are understood differently.

For achromatic colours that represent the poles (belyj 'white' and chernyj 'black'), gradability means the degree of closeness to the pole, and high degree is primarily interpreted as spotlessness and homogeneity, absence of dark touches for white, and of light touches for black: dlinnjushhie volnistye volosy... belye-belye! 'longest wavy hair... white-white' (D. Rubina); Ten' ot pletnja chjornaja-chjornaja 'The shadow of the wicker fence is black-black'. For seryj 'gray', gradability is measured along the scale from lighter to darker grays, and high degree is interpreted as being neither lighter nor darker than the middle of the gray spectre. It also means the absence of any other hues, such as blue, green, pink, etc.: Nebo seroe-seroe, nigde ne vidat' prosveta 'The sky is gray-gray, no opening in the clouds anywhere' (A. A. Allendorf); Ves' zal byl takoj seryj-seryj, a ona sidela $v$ rozovoj koftochke 'The whole audience was gray-gray, and she alone was wearing a pink blouse' (Julija Korlyhanova).

For chromatic colours, gradability also means closeness to the prototype, but the prototype is different - it is characterized by brightness and being in the middle of the spectrum for that colour, not by spotlessness: krasnyj-krasnyj 'red-red' refers to bright "middle" red, not to dark red, light red or dull red, and the same is true of 'green-green', 'yellow-yellow', 'carroty red — carroty red' and 'light blue — light blue': krasnaja-krasnaja krov' 'red-red blood' (N. Cyrlin), Zelenaja-zelenaja trava, gustaja, neizmjataja 'Green-green grass, thick, uncrumpled' (N. V. Kozhevnikova), Lico u nee staroe, a volosy molodye - jarkie takie, ryzhie-ryzhie, kak u lisy 'She has an old face but young hair - bright, carroty red-carroty red, like a fox' (Dina Sabitova).

Sinij-sinij 'medium to dark blue' seems to possess more than one prototype and can therefore refer both to bright hues (sinie-sinie glaza 'blue-blue eyes') or intensive dark hues (sinee-sinee nochnoe nebo 'blue-blue night sky').

Colour terms that are reduplicated more frequently can also occur in the constructions of partial reduplication with the prefix pre 'overly': belyj-prebelyj 'white-overlywhite', chernyj-prechernyj 'black-overly-black', sinij-presinij 'dark to medium blue overly dark to medium blue'. The two polar colours, 'white' and 'black', also occur in comparative construction: belee belogo 'whiter than the white', chernee chernogo 'blacker than the black'.

Colour terms that cannot be reduplicated, such as 'brown', 'purple', 'lilac', etc. are not gradable, and they either cannot be bright, or do not possess a clear prototype.

The presence of a prototype in basic colour terms and its absence in the non-basic is attested by another linguistic fact - the possibility of a reference comparison. All basic colours possess standard comparisons in Russian. The most basic colours, 'white' and 'black', possess the largest number of standard comparisons: belyj kak sneg/ moloko/ bumaga/ polotno/ saxar/ kipen',... 'white as snow/ milk/ paper/ sugar/ foam,..', chernyj kak noch' smol'/ ugol'/ sazha/ zhuk/voronovo krylo 'black as night / pitch/coal/ soot/beetle/raven's wing'. 
The middle of the hierarchy of basicness is also well-represented: krasnyj kak krov'/ $\mathrm{rak} / \mathrm{pion}$ 'red as blood/crawfish/peony', sinij kak nochnoe nebo/vasil'ki 'dark blue as night sky/ 'medium-to-dark-blue as a cornflower', goluboj kak nebo 'light blue as sky', zelenyj kak trava 'green as grass', zheltyj kak limon/jantar' 'yellow as lemon/amber'.

Indeed, all basic colour terms have standard reference comparisons; gray does too (seryj kak mysh'/pepel 'gray as a mouse/ashes') and so does the Russian original term for 'dark orange' - ryzhij 'red, coppery, carroty' (ryzhij kak ogon'/solnce 'as fire, as the sun').

Interestingly, many of the standard reference comparisons reflect the "universals of human experience" that Anna Wierzbicka postulates in connection with colour terms (Wierzbicka 2005). However, there are no standard reference comparisons for 'brown', only occasional isolated similes, such as korichnevyj kak shokolad 'brown as chocolate', korichnevyj kak pechenaja kartoshka 'brown as baked potatoes'. Nor do non-basic colour terms, such as 'pink', 'lilac' or 'violet' possess standard reference comparisons. As stated above, the absence of a prototype prevents colour terms from being reduplicated because the construction of reduplication denotes closeness to the prototype.

However, the question remains - what explains different frequencies of gradable reduplicated colour terms? To answer that question, one has to examine typical collocations of reduplicated colour terms with nouns. The list of typical collocates with reduplicated colour terms according to the data from the Russian National Corpus is presented below:

sinij-sinij 'medium-to-dark blue-medium-to-dark blue': 'sky', 'eyes', 'mountains', 'sea', 'hands'

belyj-belyj 'white-white': 'hands', 'face', 'skin', 'snow', 'sand', 'doves', 'shirt' chernyj-chernyj 'black-black': 'eyes', 'shadow', 'sky'

ryzhij-ryzhij 'coppery-red - coppery-red': 'man', 'girl' (about hair)

goluboj-goluboj 'light-blue-light-blue': 'eyes', 'sky', 'water'

seryj-seryj 'gray-gray': 'sky', 'day', 'face'

krasnyj-krasnyj 'red-red': 'blood', 'cheeks', 'lips'

zelenyj-zelenyj 'green-green': 'eyes', 'grass', 'meadow'

zheltyj-zheltyj 'yellow-yellow': 'sand', 'face'

One can easily observe that not all collocations typical for non-reduplicated colour terms are possible with reduplicated. Thus, for semantic reasons reduplication is impossible in terminological collocations because the high degree reading is not available: *Krasnaja-Krasnaja armija 'Red-Red Army', *beloje-beloje vino 'white-white wine', *zelenyj-zelenyj chaj 'green-green tea'. Consequently, 'black', 'white' and 'red' which form the largest number of terminological expressions and which most frequently occur in them, are pushed down from the top of the frequency hierarchy because in this, most typical usage, they cannot be reduplicated.

As can be seen from the above list of collocates, the following semantic classes of objects encourage reduplication of the colour term they co-occur with: body parts, especially face and its parts (face, eyes, skin, lips, hair, cheeks, hands, blood), clothes shirts, dresses (usually white), and landscapes - sky, grass, water, sea, leaves. As can be inferred from the co-occurrence data of non-reduplicated colour terms, reduplication 
affects only a subclass of the most frequent combinations of nouns with colour terms namely, expressions referring to human appearance (including clothes), and human perception of the surroundings (landscapes).

What does this signify? Colour term reduplication is not only contingent on the gradability of the colour term or the cultural prominence of the objects the colours characterize, but on some other factor. What is this factor? We suggest that objects that are likely to be aesthetically or emotionally evaluated, will tend to allow reduplication in the colour term. If we look at the interpretations of reduplicated colour terms, we will find that, apart from the surprisingly high degree, they express the idea of aesthetic or emotional assessment of the highly intensive or extremely pure colour.

Indeed, the phrase golubye-golubye glaza 'blue-blue eyes' expresses not only the idea that the eyes are of a particularly bright and clear colour, but also that they are beautiful. It would be impossible to use a negative attribute with the expression golubyegolubye glaza; cf. the impossibility of *mutnye golubye-golubye glaza 'murky blueblue eyes', *xolodnye golubye-golubye glaza 'cold blue-blue eyes', *pustye golubyegolubye glaza 'vacant blue-blue eyes'.

However, without reduplication all these expressions become possible; cf. examples from the Russian National Corpus:

(1) Svetlovolosaya muchenica smotrela na menya [...] mutnymi golubymi glazami... 'The blonde martyr looked at me with her murky blue eyes' (A. Belyanin, 1999)

(2) Holodnye golubye glaza pristal'no i nedoverchivo smotreli na mal'chikov 'Cold blue eyes were looking at the boys intently and suspiciously' (A. Rybakov, 1955-1956)

(3) Muzhskaya polovina mestnogo naseleniya — desyatok vkonec spivshihsya muzhikov s pustymi bleklo-golubymi glazami

'The male half of our local population are a dozen drunkards with empty faded blue eyes' (A. Marinina, A. Gorkin).

There are also 'disgusting blue eyes', 'dirty blue eyes', 'stupid blue eyes' in the RNC, but nothing of the kind with the reduplicated colour term.

Consider other examples where colour term reduplication expresses positive aesthetic assessment of the colouring in humans and nature:

(4) Glaza eyo blesteli, zuby byli po-prezhnemu belye-belye, volosy [...] eshchyo chyornye-chyornye

'Her eyes were shining, her teeth were still white-white, hair still black-black' (A. Rybakov, 1975-1977)

(5) Uneyo byli sinie-sinie glaza, i vokrug nih byli dlinnye resnicy

'She had blue-blue eyes with long eye-lashes' (V. Dragunskij, 1963) (body parts)

(6) Zelenyj-zelenyj lug, sinee-sinee nebo, a tam, v nebe, chto-to oslepitel'no zolotoe 'Green-green meadow, blue-blue sky, and there in the sky, something blindingly bright' (B. Zahoder, 1960-1980)

(7) Trava zelenaya-zelenaya, sosny shumyat vershinami

'The grass is green-green, the tops of pine trees rustle' (D.N. Mamin-Sibiryak, 1897) (landscape) 
Therefore, reduplication construction in such examples can be interpreted as follows: ' $\mathrm{X}$ is of a very $\mathrm{Y}$ colour, and the speaker feels something very good when she sees it'. The first component reflects the semantics of Russian syntactic reduplication construction (high degree), whereas the second component has the status of a conversational implicature, and is triggered by cultural norms and expectations. Usually, in the Russian culture, blue eyes of a very clear and bright colour are considered beautiful, very green colour of the grass points to its pleasing freshness, very blue sky means a sunny day, which is, in turn, normally perceived as nice and enjoyable weather. However, since it forms an implicature, the second component is sometimes cancellable: U starukhi byli strashnye glaza, chernye-chernye 'She had scary eyes, black-black'.

Thus, colour term reduplication does not always produce the interpretation of beauty and positive emotions. Sometimes, it is just the opposite - reduplication increases negative aesthetic or emotional assessment. Consider the following examples:

(8) Nikolaj Apollonovich, staroobraznyj i kakoj-to ves' zloj, s zheltym-zheltym licom, $s$ vospalennymi dokrasna vekami

'Nikolaj Apollonovich, old and mean-looking, with a yellow-yellow face, with inflamed red eyelids' (A. Belyj, 1913-1914)

(9) Melkij dozhdik seet, kak iz sita, nebo seroe-seroe, nigde ne vidat' prosveta 'It was drizzling, the sky was gray-gray, without a glimpse of the sun' (A. Allendorf, 1910)

In such examples, reduplication construction can be interpreted as follows: ' $\mathrm{X}$ is of a very Y colour, and the speaker feels something very bad when she sees it'. Again, the second component is a conversational implicature. In these examples, the intensity of colour is interpreted negatively because of the corresponding norms and expectations concerning human appearance and surrounding nature. In the Russian language worldview, yellow is considered an unhealthy facial colour, while gray sky means rain and, thus, bad weather by the usual standards of a moderate climate.

Therefore, both human appearance and landscapes can be evaluated either positively or negatively in reduplicated colour term constructions. The interpretation depends on pragmatic factors, namely, on the standards of beauty, health, and on the understanding of the norm. If a certain colour is a desired characteristic of an object, the assessment is usually positive: 'blue-blue eyes', 'black-black eyebrows', 'white-white teeth', 'blue-blue sea', 'green-green grass'. If a certain colour is an undesired characteristic of an object, the assessment is negative.

The most typical situations where colour reduplication is interpreted negatively include negative emotions, unpleasant sensations or illnesses: 'blue-blue hands' (as a result of cold), 'yellow-yellow whites of the eyes' (as a result of jaundice), 'whitewhite/ gray-gray/ blue-blue/ green-green face' (as a result of fear, disease, or death). Reduplication also carries negative assessment when colour terms describe decay in nature ('yellow-yellow grass') or situations that are not conducive to desirable human activities - e.g., bad weather ('gray-gray sky', 'gray-gray day'), bad visibility ('black-black night'), scary environment ('black-black street', 'black-black house'). 
In certain cases, a wider context is needed to establish the correct interpretation: e.g., 'white-white face' can be either a manifestation of beauty or a sign of illness or fear, 'black-black eyes' or 'red-red lips' can be either alluring or scary.

From the list of basic colour terms that allow reduplication, only goluboj-goluboj 'light-blue' is always interpreted with positive assessment, and seryj-seryj 'gray' always with negative assessment. Ryzhij-ryzhij 'red, coppery, carroty' is perhaps the most neutral characteristic.

The hierarchy of reduplication is, thus, explained by semantic and pragmatic factors: in order to be reduplicated, a colour term has to be gradable, but also has to appear in the evaluation of beauty or norm in human appearance (eyes, hair, skin in particular) or in nature (sky, sea, grass in particular), as perceived by humans. This explains the prominence of sinij 'medium to dark blue' in the hierarchy of reduplication, as in Russian, it is the most typical characteristic of beauty in the colour of the eyes and of beautiful and hospitable natural surroundings in the colour of the sea and the sky.

\subsection{Reduplication data from the parallel corpora}

A natural question arises, as to whether the above-mentioned tendencies concerning the use of colour terms are universal or language-specific. While this paper considers Russian data, a certain cross-linguistic perspective can be provided by a brief examination of parallel corpora. Data from the Russian-English parallel corpus reveals that semantic tendencies underlying linguistic usage are shared by these two languages (and possibly possess wider cross-linguistic universality): e.g., *absolutely brown in English is as strange as *korichnevyj-korichnevyj in Russian. Yet the strategies involved in expressing high degree with colour terms are language-specific: thus, reduplication, so favored in Russian, is for the most part absent in English. Instead, English uses standard constructions and adverbial intensifiers typical for that language: 'spotlessly white snow', 'snow-white gazelle', 'deep blue sky', 'marvelously green little lawn', 'very black lashes', or else omits explicit colour intensification altogether.

However, in a few cases Russian reduplicated colour terms are rendered by the construction of repetition with a comma in English, or else, there is repetition in English originals that is translated into Russian with the use of reduplication:

(10 "Just give me one of those roses in the bunch you are wearing, will you?" The lady gave him a red, red rose (O. Henry. The Complete Life of John Hopkins (1908) 'Daite mne tol'ko rozu iz vashego buketa, ladno? Ona dala emu krasnuyu-krasnuyu rozu’ (О. Генри. Один час полной жизни (Н. Дарузес, 1950-1960)) (English original)

(11) Voobrazhayu: tikhii-tikhii, temnyi-temnyi sad, i $v$ tishine edva slyshatsya glukhie rydaniya... (А.П. Чехов. Студент (1894))

'I imagine it: the still, still, dark, dark garden, and in the stillness, faintly audible, smothered sobbing...' (Anton Chekhov. The Student (Constance Garnett, 19001930)) (Russian original) 
But such cases are extremely infrequent - not more than several occurrences in the corpus. There are also several examples of parallelism where English repetition is rendered by repetition in Russian:

(12) A man having a lavish epileptic fit on the ground in Russian Gulch State Park. Blue, blue Crater Lake (Vladimir Nabokov. Lolita (1955))

(13) Chelovek, b'yushchiisya v burnom epilepticheskom pripadke na goloi zemle, $v$ shtatnom parke Russkoi Tesniny. Sinee, sinee Kraternoe Ozero (Владимир Набоков. Лолита (В. Набоков, 1967)).

However, in this case, Nabokov's "Lolita" in its English original and Russian translation, authored by Nabokov himself, can hardly be considered representative of a general cross-linguistic tendency.

The infrequency of both types of parallelism (English repetition $\Leftrightarrow$ Russian reduplication, English repetition $\Leftrightarrow$ Russian repetition) is easily explained. For Russian, the construction of choice to express intensification with colour adjectives is the reduplication with a hyphen $(X-X)$ and not the repetition $(X, X)$. The primary meaning of the Russian repetition construction is emotional emphasis (and intensification of degree is secondary), whereas the primary meaning of reduplication is intensification of degree (and the emphasis has secondary status).

This correlates with the semantics of colour adjectives, and their usage in reduplication constructions with the meaning of intensification produces natural interpretations of bright colour, intense colour, or spotless colour. Consequently, in the Main Subcorpus of the Russian National Corpus the proportion of reduplicated colour terms to repeated colour terms (after the removal of "noise", such as repetition with the meaning of confirmation) is approximately $3: 1$. In other words, combinations like belyj-belyj 'spotlessly white', chernyj-chernyj 'pitch black', red-red 'bright red', zelenyjzelenyj 'brilliant green' are three times as frequent as belyj, belyj, chernyj, chernyj, krasnyj, krasnyj, zelenyj, zelenyj. The suggested semantic explication of this reduplication construction is as follows:

(14) $X$ is $Y$-Y (Sneg belyj-belyj 'The snow is white-white') = ' $\mathrm{X}$ is very $\mathrm{Y}$, and the speaker did not expect it'

On the other hand, the preferred fillers of the Russian repetition construction are adjectives denoting human properties, which tend to avoid reduplication, because their repetition produces a pragmatically more acceptable effect of emotional emphasis, and not pure degree intensification.

The general proportion of repetition to reduplication with "human" adjectives is $2: 1$, and adjectives expressing attitudes are top fillers in the former. Thus, combinations like milyj, milyj 'dear, dear' are twice as frequent in the corpus as combinations like milyj-milyj 'dear-dear'. The suggested semantic explication of this repetition construction is as follows:

(15) $X$ is Y, Y (Moj milyj, milyj drug 'My dear, dear friend', On strashnyj, strashnyj 'He is scary, scary') $=$ ' $\mathrm{X}$ is $\mathrm{Y}$, and the speaker feels something very good or very bad about it' 
In English, the construction of repetition appears close in meaning to the Russian construction of repetition, rather than being an equivalent of both reduplication and repetition constructions. This is confirmed by the frequency data: there are few isolated examples of the English repetition construction with colour terms, but quite a few examples of its use with adjectives denoting human qualities, especially those expressing attitudes, with dear, dear being the most frequently repeated adjective. Interestingly, repetition occurs not only in the English translations, but in English originals as well:

(16) "Yes, rabbit. My good, good rabbit. Now we go (Ernest Hemingway. For Whom The Bell Tolls (1940))

(17) And when the joke had been duly digested and they came back, she was sobbing, "Dear, dear Frona." (Jack London. A Daughter of the Snows (1902))

(18) “Wicked, wicked Darzee!” said Nag, lashing up as high as he could reach (Rudyard Kipling. The Jungle Book: Other Stories (1894))

(19) It is a mild, mild wind, and a mild looking sky (Herman Melville. Moby-Dick (1851))

(20) "Oh! thoughtless, thoughtless Lydia!" cried Elizabeth when she had finished it (Jane Austen. Pride and Prejudice (1813))

Thus, English and Russian constructions with repetition of adjectives may, at least on the basis of this preliminary data, be considered as sufficiently close equivalents. Their primary fillers are adjectives denoting human properties, especially those expressing speaker's attitude, such as 'good', 'nice', 'dear', 'wicked', 'happy', etc.

Their emphatic use in the construction of repetition appears to be a mark of a certain emotional state of mind, almost of affectation. They are frequently used in forms of address, which supports the analysis of their primary meaning as denoting a strong (often positive) emotion:

(21) Nu chego ty stesnyaeshsya, ty milyj, milyj, milyj, ya lyublyu tebya 'What are you shy of, you are nice, nice, nice, I love you' (V. Makanin, 1977).

Their comparative usage in modern texts remains a subject for further study, as current findings are based on the limited material of the Russian-English National Subcorpus of the Russian National Corpus.

Generally, the fact that repetition of such adjectives is reasonably well-represented both in English originals and English translations of Russian texts may indicate a special type of semantic shift that repetition produces when applied to 'attitude' adjectives as opposed to other semantic classes. It adds a special emotional and emphatic value to an expression, and for that reason it might be more acceptable in English, which generally avoids repetition with other semantic classes of adjectives.

Lexicographically, the fact that certain adjectives favor reduplication and other intensification constructions, such as is the case with certain colour terms, appears worth mentioning in a dictionary, especially in a dictionary of a productive type. For that reason, it is suggested that respective information about complete syntactic reduplication with a hyphen, such as belyj-belyj 'white-white', intensified reduplication with the prefix pre 'overly', such as belyj-prebelyj 'white-overly-white', and constructions with comparative, such as belee belogo 'whiter than the white' should appear in the dictionary entries of corresponding adjectives. 


\subsection{Colour term reduplication in the language of poetry}

Interestingly, certain tendencies in the functioning of reduplicated colour term constructions observed in the Main Subcorpus of the Russian National Corpus, do not seem to hold for the language of poetry. Indeed, the Poetic Subcorpus displays a nearly total lack of colour reduplications with a hyphen of the belyj-belyj type. Out of about 150 occurrences of repeated colour terms in the Poetic Subcorpus, only two are hyphenated:

(22) Vjetsja v topke plamen' belyj

Belyj-belyj, budto sneg (N. Rubtsov, 1955-1957)

'A white flame is curling in the furnace

White-white, as if snow'

(23) Utro budet sinim-sinim,

Sinim budet nebosvod (I. Utkin, 1935)

'The morning will be blue-blue,

Blue will be the sky'.

The rest of the occurrences employ repetition with a comma, which denotes emotional emphasis and is usually reserved for adjectives denoting human properties. Consider some well-known lines from the poetry of the Silver Age (there are only a few isolated examples of repeated colour terms in poetry before the turn of the century):

(24) Za oknom krylami veet

Belyj, belyj Duhov den (A. Akhmatova, 1930)

'Outside the window flutters wings

White, white Holy Spirit Monday'

(25) Vidish den' bezzakatnyj i zhguchij

I lyubimyj rodimyj svoj kraj,

Sinij, sinij, pevuchij, pevuchij,

Nepodvizhno-blazhennyj, kak raj (A. Blok, 1914)

'You see a day without sunset and fiery

And your beloved native country,

Blue, blue, sonorous, sonorous,

Blissfully motionless, as paradise'

(26) A belyj, belyj sneg do boli ochi est (O. Mandelshtam, 1922)

'And white, white snow is painfully gnawing at the eyes'

(27) Chernyj chelovek,

Chernyj, chernyj,

Chernyj chelovek

Na krovat ko mne saditsya (S. Esenin, 1923-1925)

'Black man,

Black, black,

Black man

Sits down on my bed'

How can one explain this deviation from a strong tendency found in non-poetic language for colour terms to occur in the construction of reduplication with a hyphen? 
It appears that there are two factors at play. First of all, the language of poetry, by virtue of the genre itself, is more expressive and involves more emotional emphasis than the language of prose. Thus, even in situations when the primary expected interpretation is that of degree, namely, in colour reduplication constructions, in poetry we are faced with their interpretation as constructions of emotional emphasis. Clearly, all the quoted examples carry strong sentiment. Even in cases where colour intensity is in the focus, as evidenced by the use of other degree constructions (underlined in the examples below), still the construction of choice is repetition with a comma, whose primary meaning is emotional emphasis:

(28) A sneg dymitsya kruzhevom ryzhim, Ryzhim, ryzhim, ryzhej vina (Z. Gippius, 1918-1938)

'And the snow is smoking as red lace,

Red, red, redder than wine'

(29) O temnyj, temnyj, temnyj put'

Zachem tak temen ty $i$ dolog (S. Parnok, 1922)

'Oh dark, dark, dark path

Why are you so dark and long'

Moreover, in poetic language, even terminological colour terms can be repeated in the comma construction:

(30) Budut, trepetny i zorki,

Begat' pary po rose,

I na Krasnoj, Krasnoj gorke

Obvenchayutsya, kak vse (M. Kuzmin, 1916)

'There will, tremulous and sharp-sighted,

Couples run around while the dew is still on the ground,

And at Red, Red Mountain,

Will get married, as everybody'.

'Red mountain', or Krasnaja gorka, is a folk name of the first Sunday after the Orthodox Easter. Obviously, in this idiomatic combination, 'red' is not a colour term, yet it does get repeated, because, it seems, emotional emphasis can be added to any linguistic expression. Thus, one reason for the overwhelming prevalence of repetition of colour terms over their reduplication in poetic language hinges on the very nature of poetry with its heightened expressive power and emotionality. However, there is another reason why colour reduplication is practically absent in the Corpus of poetic language. There is a certain pragmatic quality in this construction that is for the most part incompatible with poetry. Namely, it is different from repetition with a comma not only in its semantics, but also in pragmatics and register.

As reflected in its semantic explication, reduplication also carries a certain emotional load, namely, the idea of surprise at being faced with such a high degree of a certain characteristic. When we say belyj-belyj 'white-white', strashnyj-strashnyj 'scary-scary', we are not only noting a very considerable degree of whiteness or scariness, we are also expressing our surprise and trying to convey it to the hearer. This particular pragmatic message is, as it turns out, mostly limited to a particular group of speakers and addressees; namely, this quality of breathless surprise is typical of children. 
Accordingly, constructions with colour reduplication are found in the Subcorpus of Children's literature considerably more frequently than in the Main Corpus. There are 94 cases of colour reduplication with a hyphen in the Children's literature subcorpus (the total number of tokens is $5.8 \mathrm{mln}$ ), and 810 cases of colour reduplication with a hyphen in the Main Corpus, which includes Children's literature (the total number of tokens is $283 \mathrm{mln}$ ).

Thus, the absolute frequency of colour reduplication with a hyphen in the Children's literature subcorpus is 16.2 i.p.m, whereas in the Main Corpus it is only 2.8 i.p.m, i.e., over five times less. The fact that the construction with reduplication is, to an extent, a feature of children's speech or speech intended for children, may account for its rarity in the Poetic Corpus. The latter does not contain any children's poetry, and there is an apparent stylistic contradiction between the lofty style of the "adult" poetry represented there and the colloquial childish ring of the reduplication construction.

\section{CONCLUSIONS}

To sum up, our findings yield the following conclusions.

First, reduplication construction with a hyphen and repetition construction with a comma are two distinct entities in Russian. The former is characterized by prosodic unity, denotes a surprisingly high degree of a certain characteristic and is used with gradable adjectives. In different contexts, in particular, in combination with colour terms, it develops additional implicatures. The latter is pronounced as two distinct words, denotes primarily emotional emphasis, and is possible with non-gradable adjectives.

Colour terms tend to occur in the reduplication with the meaning of high degree: belyj-belyj 'white-white, very white, spotlessly white'.

However, not all colour terms are equally possible with reduplication: while certain terms, such as fioletovyj 'purple', cannot be reduplicated, others, such as chernyj 'black', goluboj 'light blue', belyj 'white' are perfectly possible in this construction. Moreover, certain color terms, such as sinij 'medium-to-dark blue', demonstrate unexpectedly high percentages of reduplicated forms. Their level of compatibility with reduplication construction partly depends on their gradability, which, in turn, somewhat parallels Berlin-Kay hierarchy of basic colour terms. However, there are additional pragmatic factors that influence the ability of colour terms to occur in the hyphenated reduplication construction. Namely, colour terms that co-occur with the names of culturally and cognitively salient objects, such as denotations of human appearance (face, hands, skin, eyes, hair) or landscape features (sea, sky, fire, grass) are more likely to be used in constructions of reduplication. Moreover, aesthetic or emotional evaluation of such objects ('blue-blue eyes', 'green-green grass') is also a factor that is conducive to their occurrence in the construction of reduplication.

The hierarchies of basic colour terms are to an extent language-specific: e.g., in Russian, goluboj 'light blue' and ryzhij 'carroty-red' have a claim for basicness, due to their salience as characteristics of human appearance and/or natural surroundings.

Reduplication of colour terms is to an extent register-specific: namely, it is almost absent in the language of poetry. Instead, in poetic language, comma repetition of colour terms (belyj, belyj 'white, white') with the meaning of emotional emphasis dominates 
their reduplication with the meaning of high degree (belyj-belyj 'white-white'). This deviation may be explained by the stylistic limitations of reduplication with a hyphen, which tends to be a feature of children's literature, as well as by heightened emotionality of the language of poetry as compared to other language registers.

To sum up, our findings establish the importance of corpus methods in the study of colour terms and reduplication, demonstrate that the use and interpretation of lexical and syntactic items hinges both on semantic and pragmatic factors, and add to the understanding of semantics and pragmatics of Russian colour terms and reduplication construction.

(C) Valentina Apresjan, 2018

\section{REFERENCES}

Apresjan, J. (2006). The foundations of systemic lexicography. Linguistic picture of the world and systemic lexicography. Moscow: Yazyki slavyanskikh kul'tur. (In Russ.).

Apresjan, V., Baisa V., Buivolova O., Kultepina O., Maloletnjaja A., Iskhakov T., Suchomel V. (2016). RuSkELL: Online Language Learning Tool for Russian Language. In T. Margalitadze, G. Miladze (eds.), Proceedings of the XVII Euralex International Congress, 292-299.

Berlin B., Kay, P. (1969). Basic Colour Terms: their Universality and Evolution. UCP Press.

Bulygina, T.V., Shmelev, A.D. (1997). Yazykovaya kontseptualizatsiya mira (na materiale russkoi grammatiki) (Linguistic conceptualization of the world (from the evidence of the Russian grammar)). Moscow: Shkola "Yazyki russkoi kul'tury". (In Russ.).

Davies, I., Corbett, G. (1994). The basic colour terms of Russian. Linguistics, 32(1), 65—90.

Feldstein, R.F. (2016). On Russian concessive-adverstaive constructions with pronominal reduplication of the type "Uzh chem-chem, a etim ego ne udivish". In Trudy Instituta russkogo yazyka im. V.V. Vinogradova (The working papers of Vinogradov Russian Language Institute), 11, 329-342. Moscow.

Gilyarova, K.A. (2015). Takaya devochka-devochka. Semantika reduplikatsii sushchestvitel'nykh $\mathrm{v}$ russkoi razgovornoi rechi i yazyke internet (Such a girl-girl. Semantics of noun reduplication in colloquial Russian and the Internet language). In Dialogue'2015, Computer Linguistics and Intellectual Technologies, 90-96. (In Russ.).

Iomdin, L.L. (2003). Bol'shie problemy malogo sintaksisa (Big problems of the minor syntax). In Computational Linguistics and Intellectual Technologies: Proceedings of the International Conference "Dialog”, 216-222. (In Russ.).

Iomdin, L. (2010). Sintaksicheskie frazemy: mezhdu leksikoi i sintaksisom (Syntactic phrasemes: between lexicon and syntax). In Apresjan Ju. (ed.), Teoreticheskie problemy russkogo sintaksisa: vzaimodeistvie grammatiki $i$ slovarya (Theoretical problems of the Russian syntax: interaction of grammar and lexicon). Moscow: Yazyki slavyanskikh kul'tur, 141-190. (In Russ.).

Iomdin, L.L. (2013). Chitat' ne chital, no...: ob odnoi russkoi konstruktsii s povtoryayushchimisya slovesnymi elementami (I haven't read it but...about one Russian construction with repeated elements). In Computational Linguistics and Intellectual Technologies: Proceedings of the International Conference "Dialog”, 12 (19), 297-310. (In Russ.).

Israeli, A. (1997). Syntactic Reduplication in Russian: A Cooperative Principle Device in Dialogues. Journal of Pragmatics 27, 587-609.

Kilgarriff, A., Baisa, V., Bušta, J., Jakubíček M., Kovář V., Michelfeit J., Rychlý P., Suchomel V. (2014). The Sketch Engine: ten years on. Lexicography, 1 (1), 7-36. 
Kryuchkova, O.Yu. (2004). Voprosy lingvisticheskoi traktovki leksicheskoi reduplikatsii v russkom yazyke (The issues of linguistic interpretation of lexical reduplication in the Russian language). Russkii yazyk $v$ nauchnom osveshchenii [Russian Language and Linguistic Theory], 2(8), 63-83. (In Russ.).

Lyashevskaya, O. N., Sharov, S. A. (2009). Chastotnyj slovar' sovremennogo russkogo jazyka (na materialah Nacional'nogo korpusa russkogo jazyka) [Frequency Dictionary of Modern Russian Language (on the material of the National Corpus of the Russian language)]. Moscow: Azbukovnik. (In Russ.).

Paillard, D., Plungian, V. A. (1993). Ob odnom tipe konstruktsii s povtorom glagola v russkom yazyke (On a type of constructions with the repetition of verbs in Russian). Russian Linguistics, 17 (3), 263-277. (In Russ.).

Paramei, G. (2005). Singing the Russian blues: An argument for culturally basic colour terms. CrossCultural Research, 39, 10-38.

Paramei, G. (2007). Russian 'blues': Controversies of basicness. In R.E. MacLaury, G.V. Paramei, \& D. Dedrick (eds.), Anthropology of colour: Interdisciplinary multilevel modeling, 75-106. Amsterdam: John Benjamins.

Plungjan, V. A., Rakhilina, E. V. (2010). Tushat-tushat - ne potushat: grammatika odnoi glagol'noi konstruktsii (Tushat-tushat - ne potushat: the Grammar of one Verbal Construction). In Rakhilina E. V. (ed.), Lingvistika konstruktsii (Construction Linguistics), 83-94. Moscow: Azbukovnik. (In Russ.).

Stefanowitsch, A., Gries S. 2003. Collostructions: Investigating the interaction between words and constructions. International Journal of Corpus Linguistics, 8(2), 209-43.

Vilinbakhova, E. L. (2015). Stat'ya znachit stat'ya: ob odnom klasse tavtologicheskikh konstruktsii v russkom yazyke (An article means an article: on one class of tautological constructions in Russian). In Computational Linguistics and Intellectual Technologies: Proceedings of the International Conference "Dialog”, 1(14), 2, 638 - 649. (In Russ.).

Wierzbicka, A. (1990). The meaning of colour terms: Semantics, culture, and cognition. Cognitive Linguistics, 1(1), 99-150.

Wierzbicka, A. (2003). Cross-cultural Pragmatics: The Semantics of Human Interaction. 2-nd edition. Mouton de Gruyter.

Wierzbicka, A. (2005). There Are No "Colour Universals" but There Are Universals of Visual Semantics. Anthropological Linguistics, 47(2) (Summer, 2005), 217-244.

Wierzbicka, A. (2008). Why There Are No 'Colour Universals' in Language and Thought. The Journal of the Royal Anthropological Institute, Vol. 14, No. 2 (Jun., 2008), 407-425.

Wierzbicka, A. (2013). Imprisoned in English. The Hazards of English as a Default Language. Oxford University Press.

Winawer, J., Witthoft, N., Frank, N.C., Wu L., Wade A.R. and L. Boroditsky. (2007). Russian blues reveal effects of language on colour discrimination. Proceedings of the national academy of sciences, 104 (19), 7780-7785.

\section{Article history:}

Received: 18 April 2018

Revised: 15 May 2018

Accepted: 29 June 2018

\section{История статьи:}

Дата поступления в редакцию: 18 апреля 2018

Дата принятия к печати: 29 июня 2018 


\section{For citation:}

Apresjan, Valentina (2018). Russian Constructions with Syntactic Reduplication of Colour Terms: A Corpus Study. Russian Journal of Linguistics, 22 (3), 653 - 674. doi: 10.22363/2312-9182-201822-3-653-674.

\section{Для цитирования:}

Apresjan, Valentina. Russian Constructions with Syntactic Reduplication of Colour Terms: A Corpus Study // Вестник Российского университета дружбы народов. Серия: Лингвистика = Russian Journal of Linguistics. 2018. T. 22. № 3. C. 653 - 674. doi: 10.22363/2312-9182-2018-22-3-653-674.

\section{Bionote:}

VALENTINA APRESJAN is currently working as an Associate Professor at the National Research University "Higher School of Economics" (School of Linguistics), as well as the leading researcher at Vinogradov Russian Language Institute (Sector for Theoretical Semantics). She received her Ph.D from the University of Southern California (Emotion conceptualization in Language, 1996), and her Dr. Habilitatus degree from Vinogradov Russian Language Institute (Formation and Interaction of Compex Meanings in Language, 2015). Valentina Apresjan taught at USC (1994-1996), AlpenAdria-Universität Klagenfurt (2000), Russian State University of Humanities (2008-2010), Dartmouth College (2010-2012, 2016-2018). Her research interests include semantics, pragmatics, semantic typology, lexicography, constructions.

Contact information: valentina.apresjan@gmail.com, vapresyan@hse.ru

\section{Сведения об авторе:}

ВАЛЕНТИНА ЮРЬЕВНА АПРЕСЯН - профессор Школы лингвистики в Национальном исследовательском университете «Высшая школа экономики», а также ведущий научный сотрудник Сектора теоретической семантики в Институте русского языка им. В.В. Виноградова РАН. Она защитила кандидатскую диссертацию по лингвистике в Университете Южной Калифорнии в 1996 году по теме «Концептуализация эмоций в языке» и докторскую диссертацию по специальности «Теория языка» в 2015 году в ИРЯ РАН. Она преподавала в Университете Южной Калифорнии, США, в Университете Клагенфурта, Австрия, в Дартмутском колледже, США. Ее исследовательские интересы включают семантику, прагматику, конструкции, семантическую типологию и лексикографию.

Контактная информация: valentina.apresjan@gmail.com, vapresyan@hse.ru

\section{FINANCE AND ACKNOWLEDGMENTS}

This work was supported by the grant of the Russian National Humanities Fund for 2016 - 2018, № 16-04-00302 "Preparation of the third issue of the Active dictionary of Russian" (principal investigator Yu.D. Apresyan).

I would also like to thank my anonymous reviewers, as well as the editors of this volume, for their valuable comments.

\section{БЛАГОДАРНОСТИ И ФИНАНСИРОВАНИЕ}

Статья написана при поддержке РФФИ, грант № 16-04-00302 2016-2018 «Подготовка третьего выпуска Активного словаря русского языка» (руководитель НИР Ю.Д. Апресян).

Я также благодарю анонимных рецензентов и редакторов выпуска за ценные комментарии к этой статье. 